\title{
Hydrological elements for ecosystem conservation: a comprehensive water management for a binational wetland in the arid northwest of Mexico.
}

\author{
Marcelo A. Lomeli-Banda ${ }^{1}$, Jorge Ramírez-Hernández ${ }^{1}$, J. Eliana Rodríguez-Burgueño ${ }^{1}$ \\ and Carlos Salazar-Briones ${ }^{1}$ \\ ${ }^{1}$ Universidad Autonoma de Baja California
}

July 7, 2020

\begin{abstract}
The water agreements between Mexico and the United States have been crucial to restore and preserve the wetlands of the Colorado River Delta. Nowadays, the increase of water demand and climate change in the northwest of Mexico could threaten the conservation of the Cienega de Santa Clara, a coastal wetland composed of 4,709 ha of marsh area in the limits of the Sonoran Desert. This ecosystem was recognized internationally by the international Ramsar convention for playing vital ecological roles, including the habitat service for endemic, endangered and migratory species. Since the inflow reductions by the trial run of the Yuma Desalting Plant during 2010-2011, and earlier events, the hydrology of the wetland has not been completely understanding due to accessibility. Therefore this study was conducted to obtaining the hydrological elements to conserve the wetland, analyzing three scenarios: 1] normal inflow conditions of the Wellton-Mohawk canal; 2] inflow reductions, and; 3] an increase of temperature in consequence of global warming. Water and mass balances were conducted every month during one year; in-situ measurements of inflows were carried out on Wellton-Mohawk, Riíto Drain, groundwater, and precipitation; also were including evapotranspiration outputs estimated using local weather registers and Penman-Monteith formulations. The implications of the increase in temperature considered include the Intergovernmental Panel on Climate Change projections for the one hundred years. Finally, the results showed superficial water disconnections between the hydrological system of the wetland and the Gulf of California. This behavior was observed in the three scenarios, mainly in the summer months. A continuous disconnection reduced the wetland area and the water storage. Therefore, the hydrological functionality of the wetland depends on the water supply thru Wellton-Mohawk canal, which was determinate that at least a continuous discharge of $5.10 \mathrm{~m}^{3} \mathrm{~s}^{-1}$ during summer months is needed to maintain its functionality.
\end{abstract}

\section{Hosted file}

Main Document.docx available at https://authorea.com/users/340611/articles/467765hydrological-elements-for-ecosystem-conservation-a-comprehensive-water-management-for-abinational-wetland-in-the-arid-northwest-of-mexico

\section{Hosted file}

Figure 1.docx available at https://authorea.com/users/340611/articles/467765-hydrologicalelements-for-ecosystem-conservation-a-comprehensive-water-management-for-a-binationalwetland-in-the-arid-northwest-of-mexico

\section{Hosted file}

Figure 2.docx available at https://authorea.com/users/340611/articles/467765-hydrologicalelements-for-ecosystem-conservation-a-comprehensive-water-management-for-a-binational- 
wetland-in-the-arid-northwest-of-mexico

\section{Hosted file}

Figure 3.docx available at https://authorea.com/users/340611/articles/467765-hydrologicalelements-for-ecosystem-conservation-a-comprehensive-water-management-for-a-binationalwetland-in-the-arid-northwest-of-mexico

\section{Hosted file}

Figure 4.docx available at https://authorea.com/users/340611/articles/467765-hydrologicalelements-for-ecosystem-conservation-a-comprehensive-water-management-for-a-binationalwetland-in-the-arid-northwest-of-mexico

\section{Hosted file}

Figure 5.docx available at https://authorea.com/users/340611/articles/467765-hydrologicalelements-for-ecosystem-conservation-a-comprehensive-water-management-for-a-binationalwetland-in-the-arid-northwest-of-mexico

\section{Hosted file}

Figure 6.docx available at https://authorea.com/users/340611/articles/467765-hydrologicalelements-for-ecosystem-conservation-a-comprehensive-water-management-for-a-binationalwetland-in-the-arid-northwest-of-mexico

\section{Hosted file}

Figure 7.docx available at https://authorea.com/users/340611/articles/467765-hydrologicalelements-for-ecosystem-conservation-a-comprehensive-water-management-for-a-binationalwetland-in-the-arid-northwest-of-mexico

\section{Hosted file}

Figure 8.docx available at https://authorea.com/users/340611/articles/467765-hydrologicalelements-for-ecosystem-conservation-a-comprehensive-water-management-for-a-binationalwetland-in-the-arid-northwest-of-mexico

\section{Hosted file}

Figure 9.docx available at https://authorea.com/users/340611/articles/467765-hydrologicalelements-for-ecosystem-conservation-a-comprehensive-water-management-for-a-binationalwetland-in-the-arid-northwest-of-mexico

\section{Hosted file}

Figure 10.docx available at https://authorea.com/users/340611/articles/467765-hydrologicalelements-for-ecosystem-conservation-a-comprehensive-water-management-for-a-binationalwetland-in-the-arid-northwest-of-mexico

\section{Hosted file}

Figure 11.docx available at https://authorea.com/users/340611/articles/467765-hydrologicalelements-for-ecosystem-conservation-a-comprehensive-water-management-for-a-binationalwetland-in-the-arid-northwest-of-mexico

\section{Hosted file}

Figure 12.docx available at https://authorea.com/users/340611/articles/467765-hydrologicalelements-for-ecosystem-conservation-a-comprehensive-water-management-for-a-binationalwetland-in-the-arid-northwest-of-mexico 


\section{Hosted file}

Table I.xlsx available at https://authorea.com/users/340611/articles/467765-hydrologicalelements-for-ecosystem-conservation-a-comprehensive-water-management-for-a-binationalwetland-in-the-arid-northwest-of-mexico

\section{Hosted file}

Table II.xlsx available at https://authorea.com/users/340611/articles/467765-hydrologicalelements-for-ecosystem-conservation-a-comprehensive-water-management-for-a-binationalwetland-in-the-arid-northwest-of-mexico 